\title{
Responsibility in an Era of Modern Technology and Nihilism, Part 1. A Non-Foundational Rereading of Jonas
}

\author{
ERNST WOLFF University of Pretoria
}

\begin{abstract}
The aim of this two-part article is to develop a non-foundational re-reading of Jonas' ethics. In Part 1 the argument is situated within Jonas's concern with and understanding of nihilism. In order to delineate the proposed non-foundational reading, a philosophical and a theological discursive type in Jonas's work is identified and the limits and failures thereof are discussed. In stead of the metaphysical foundation of ethicity, a re-reading of his work is developed out of his myth. This reading maintains the initial aim of defeating nihilism. The limitations and possibilities of this alternative reading of the philosophy of responsibility are explored.
\end{abstract}

RÉSUMÉ : L'objectif de cet article en deux parties est de développer une relecture non-fondationnelle de l'éthique de Jonas. Dans la première partie, l'argumentation contextualise la critique de Jonas contre le nihilisme. Afin de délimiter la lecture non-fondationnelle que nous proposons, deux types de discours, philosophique et théologique, sont identifiés dans l'œuvre de Jonas dont nous discutons les limites et défauts. Son mythe permet de développer une relecture non métaphysique de l'éthicité. Cette lecture alternative de la philosophie de la responsabilité, qui maintient le but initial de Jonas de surmonter le nihilisme, comporte des limites et des possibilités.

\section{Introduction}

Jonas's entire philosophy for the "technological civilization" is strongly motivated by his concern for human (and other) life and his desire for the kind of reflection that could guide caring action towards life in a context in which life

Dialogue 48 (2009), 577-599.

(C) Canadian Philosophical Association/Association canadienne de philosophie, 2009 doi:10.1017/S0012217309990138 
is seriously threatened by new technologies. However, this project is haunted by the problem of nihilism and thus also by the need to overcome nihilism. In fact, the changing nature of human action (brought about by modern technology) and the predicament of the loss of a unifying reference for the evaluation of action (the problem of nihilism) are so intimately linked that it would make no sense to be concerned with one without being concerned about the other. In recognizing this close connection between the order of capability and the order of meaning, Jonas remains true to one of the central lessons that he learned from Heidegger's philosophy of Dasein. In fact, the extension of the implications of the co-originarity of meaning and action in the phenomenon of care, as analyzed by Heidegger, to cover not only Dasein but the entire phenomenon of life forms the backbone of Jonas's strategy of overcoming nihilism.

Although this statement of the basic position of Jonas's later work appears to be quite simple, the manner in which he went about addressing this philosophical problem lends itself to a plurality of readings.

The aim of my two articles on the work of Jonas is (1) to foreground an interpretational approach that has not yet been explored and (2) to use this approach to clarify a number of issues in Jonas's work that seem to deserve more attention than they have received thus far. Focusing my attention on Jonas's work after his studies on Gnosticism, I proceed by first situating his concern with nihilism in his philosophy and explaining what it means to him (§2). For strategic reasons, I then distinguish a philosophical and a theological voice or discursive type in Jonas’s work (§3). This step is needed in order carefully to lay out what Jonas is not attempting to do, or is not capable of doing, and what the claims of validity would be in each case if one were to follow the distinction between these two discursive types. The limitations of both these types seem to lead Jonas's philosophy into a dead end. However, I propose a different strategy to read Jonas, namely from the point of view of his myth (§4). This is certainly not Jonas's manner of presenting and reading his own work, but exploits a latent possibility in his work. I then argue how the intention and aim of the work of Jonas, especially his response to the challenge of nihilism, should be understood in the light of this reading strategy ( 5 ). In conclusion, I reflect on the benefits and limitations of this proposed rereading of Jonas's work (§6).

In a second article, ${ }^{1}$ I shall pursue a number of issues of interpretation regarding Jonas's thinking on responsibility that flow from the arguments in the current article.

\section{Diagnosis of Contemporary Culture: Nihilism or the Death of God}

Probably Jonas's best known - and highly influential - essay on nihilism is "Gnosticism, existentialism, and nihilism" (PL ${ }^{2}$ chapter 9). Here Jonas argues that there is an analogy between the nihilistic experience of Gnosticism and that of (Heideggerian) "existentialism" (PL 212). The essence of this analogy (and the difference) between the two experiences is encapsulated in the following comment: 
Gnostic man is thrown into an antagonistic, antidivine, and therefore antihuman nature, modern man into an indifferent one. Only the latter case represents the absolute vacuum, the really bottomless pit. . . This makes modern nihilism infinitely more radical and more desperate than gnostic nihilism ever could be for all its panic terror of the world and its defiant contempt of its laws. That nature does not care, one way or the other, is the true abyss. That only man cares, in his finitude facing nothing but death, alone with his contingency and the objective meaninglessness of his projecting meanings, is a truly unprecedented situation. (PL 233)

Jonas's debate with Heidegger need not detain us here. ${ }^{3}$ It is important, however, to note that the need to reconsider an interpretation of nature is already hinted at in this passage. But before we get to that important aspect of Jonas's work, let us consider in more detail what nihilism or the death of God (both expressions used in PL 224f, 232) entails, according to Jonas.

The "nihilistic situation" or the "contemporary impasse of ethical theory" (PE 169) that characterizes our "nihilistic stage" of history (PE 176) or the "crisis of modern man" (PE 168) is unpacked systematically in Jonas's essay "Contemporary Problems in Ethics from a Jewish Perspective" (PE chapter $8^{4}$ ). "Reason triumphant through science has destroyed the faith in revelation, without, however, replacing revelation in the office of guiding our ultimate choices. . . The failure is reflected in the failure of contemporary philosophy to offer an ethical theory, i.e., to validate ethical norms as part of our universe of knowledge," Jonas comments on the opening page of the essay (PE 168). He proposes to interrogate the reasons that "caused the great Nothing with which philosophy today responds to one of its oldest questions - the question of how we ought to live" (PE 168). In essence, this is due to three interrelated modern phenomena that severely undercut the ethical orientation provided by both the philosophical and the religious traditions. These are (PE 169-176):

1. Modern concept(s) of nature, of which Heidegger is a representative, as already stated, but to which various sciences have also contributed: this scientific concept of nature denies the existence of a creator who would instill the creation with a measure or benchmark and thus leaves humankind with a world that is indifferent to good and evil. Pious obedience to a creator is replaced by the vertigo of a minute humanity suspended over the abysmal immensity of a universe without any ultimate meaning, evolving with a blind, inherent logic towards a future without any purpose. ${ }^{5}$

2. Modern concept(s) of the human being: the scientific concept of nature extends logically to the image we now have of humans - they are products of this blind natural process, the champions of an endless struggle for survival and authors of the role they have to play in history. The values guiding and shaping their existence do not come from the voice of God resounding in their hearts, but from the superego and the natural 
drives that impose themselves on decision-making, behind their backs, as it were. It should come as no surprise, then, that values are changing, plural, relative, particular, subjective, conditional, conventional, and (at least for their inventors) convenient. Deprived of an ultimate point of reference and the rational means to make sense of this cacophony, humans are nonetheless de facto placed in the position of ultimate judges of what is desirable and in charge of the implementation thereof. ${ }^{6}$

3. Modern technology: weakened in their capability to orient action, humans ironically now find themselves equipped with hitherto unparalleled means of action. With these new means, they have gained mastery over purposeless nature. To an ever-increasing extent, technology places humanity on the empty throne of God (but without being the masters of their own home, in terms of the image Freud used), even to the point of being able to re-create human beings in a chosen image. ${ }^{7}$

This "impasse of ethical theory," this "death of transcendence" (PE 176), is modern culture's default conviction - if this is to be changed, enormous effort will be required. This is precisely the task that Jonas set himself.

\section{First Approach: Distinguishing Two Voices in the Answer to Nihilism}

To be sure, Jonas does not distinguish systematically between the "death of God" as a philosophical notion (equivalent to nihilism) and the possibility of a religious death of God; in fact, to a certain extent, in some texts he tends to conflate the two notions. ${ }^{8}$ Perhaps this has something to do with the fact that, as a historian of ideas and their development, he is sensitive to the effective history of religious ideas in philosophy. ${ }^{9} \mathrm{Be}$ that as it may, it is perhaps helpful, as a first step, to approach Jonas's work on this question by attempting to distinguish two registers or two voices or, to put it differently, two discursive practices of his polemics with the death of God. Doing so has the advantage of correctly identifying in each case what the strategy and stakes of his argument are. I make this distinction in order to show clearly what Jonas does attempt and what he does not attempt to do. However, after being used to gain some initial insight by means of this distinction between these two voices, I will later abandon this approach for a completely different one.

\subsection{The Theological Voice: A Personal Choice Seeking Resonance with Tradition}

Jonas does not present his discourse on God in his theological voice (provided that one adopts the proposed provisional dual-voice reading), of which the essay on the notion of God after Auschwitz is certainly the most remarkable text, as a justification for the rehabilitation of what has been lost through nihilism, or at least, if he does so, only in a very qualified manner, although this discourse does open up reflection on ethics. Jonas explicitly specifies that he does not attempt such a justification. He makes it very clear that his intellectual discourse 
on God is rather of the nature of "metaphysical suppositions" (metaphysische Vermutungen) and that it does not aspire to universal validity. One should note the title of the last section of Philosophische Untersuchungen und metaphysische Vermutungen: "Without defence against the objector: thoughts about God" (Dem Fragenden unverwehrbar: Gedanken über Gott). ${ }^{10}$ Concerning the nature of his reflection about God in the Auschwitz essay, Jonas makes the following categorical claim:

I say indeed in the beginning of the text on the notion of God after Auschwitz something like: "Whoever doesn't want to let go of the notion of God despite everything - and the philosopher also has a right to this -, has to...." etc. There I appealed to something that is not at all based any further. Whoever doesn't want to let go of the notion of God, despite all of these experiences - by this is indicated that one can obviously let go of it. The alternative of atheism remains open and can never be refuted. The answer to Auschwitz could quite perfectly be this: there is no God, in no meaningful way can there be a God that allows this. Or: something that rules, but that allows this, cannot [validly be God].

In other words, I have chosen for myself the alternative that can not at all be based any further, that I want to hold on to the notion of God: full stop. I gave no reason for doing what I do; and the alternative is left perfectly open, that is, the atheistic answer to that which took place in this century - the terrible things of which world history is not poor. Now, the way out, that I have thought out for myself was first of all for myself a way out that allowed me to hold on to the notion of God. ${ }^{11}$

Already in this formulation of the decision to pursue a discourse on God on the basis of an unfounded and personal desire to do so, it is clear that the alternative (namely not pursuing such a discourse on God) remains entirely conceivable and that, by implication, Jonas does consider it in his thinking. Furthermore, the latter alternative is supported by Jonas's estimation of what contemporary philosophy is capable of doing (or not capable of doing) - that is, the apparent intellectual impossibility of bridging the gap between what is and ought to be in a valid manner by recourse to a personal God, but also by means of (non-religious) thought - since both of these positions draw their authority equally from "highly problematic sources": the refusal to adopt a discourse on God fares as badly as the discourse on God. For this reason, it should be considered to be at least of equal merit.

If it is true then that Jonas considers the source of authority available to a religious discourse on God as highly problematic and that the discourse that he practises was adopted on the basis of personal reasons that can make no appeal, at least no appeal that could claim to being founded, to anybody else, one may conclude that this opposition to the death of God or this response to the "impasse of ethical theory" should be considered valid for or of use only to the individual (in this case, Hans Jonas), but need not have any effect beyond that, except, of course, for readers who want to follow his example, but again without any 
universally valid grounds for doing so. It should thus be admitted that even in his theology or his religious discourse on God, Jonas makes enormous concessions to the notion of the "death of God" (or at least to the death of the God of the traditional monotheisms) by the very status he is willing to give to those statements. The same could be said of the very myth of God that externalizes himself in the world and withdraws from the world and that plays such an important role in Jonas's work - for as long as this myth is read simply theologically. (I will return to the use of Jonas's myth of the abandonment of God in more detail later.)

These short observations do not, however, amount to discarding the influence of religious ideas in Jonas's work. But it is true that his Jewish faith's "validity and vitality extend beyond the reaches of faith" (cf. PE 24, cited above). The "God" that has to be salvaged from death, the orientation that would allow us to resist the power of nihilism, has to be sought by other means. This project is announced at the end of The Phenomenon of Life:

$[\mathrm{O}]$ nly an ethics which is grounded in the breadth of being, not merely in the singularity or oddness of man, can have significance in the scheme of things. It has it, if man has such significance; and whether he has it we must learn from an interpretation of reality as a whole, at least from an interpretation of life as a whole. But even without any such claim of transhuman significance for human conduct, an ethics no longer founded on divine authority must be founded on a principle discoverable in the nature of things, lest it fall victim to subjectivism or other forms of relativism. (PL 284)

This task is performed in Das Prinzip Verantwortung in such a manner as to support the central convictions of the book: "Thus we say that a 'command' can issue not only from a commanding will, for instance, of a personal God, but also from the immanent claim of a good-in-itself to its realization" (PV 153/IR 79). ${ }^{12}$

Jonas states explicitly that his way out of the impasse of ethical theory does not require his readers to pay any allegiance to a personal God: "The question of a possible ought-to-be is to be answered independently from religion" (PV 99; IR translates “. . . is for philosophy to answer"). ${ }^{13}$ He maintains the same stance in the later texts: "Responsibility thus exists with or without God" (PUV 131). Jonas's project consists of a philosophical reflection that takes us beyond the nihilistic dualisms to a teleology of nature and eventually to an explicit justification of the transition from is to ought. As a first result, this project will not so much provide the content of a positive ethics as delineate the obligation for the maintenance of the ethical agent as an ethical agent, and (as Jonas said, while explaining the ethical contribution that Judaism could make in modern times) will at least indicate what we should not do (cf. PE 181).

The first conclusion to be drawn from this short presentation of the "theological voice" in Jonas's work is that it helped to make room for different, opposing 
kinds of statements concerning the justification of ethics after the death of God. This is important in order to avoid rash conclusions concerning the religious or theological status of the God that has to be brought back to life: according to the theological and philosophical convictions of Jonas, there is no particular need to take recourse to the God of religion in order to overcome nihilism. Or to put it differently, Jonas does not use a discourse on God in order to overcome nihilism; he is convinced that a discourse on God cannot play this role, except in the case of an individual believer. Having gleaned this perspective, I shall next consider Jonas's "philosophical voice" before abandoning this dual-voice strategy for a completely different one.

\subsection{The Philosophical Voice: Founding an Ethics of Responsibility on an Ontology of Life}

From the short considerations concerning his "Jewish or theological voice" on God (above), I now turn to Jonas's "philosophical voice" on "God," which is charged with "grounding ethics in the breadth of being."

As I indicated in the introduction to this essay, Jonas's strategy in going about this task was inspired by Heidegger. The paradox of using Heidegger to overcome Heidegger's nihilism has been clarified by Taminiaux: Jonas uses the Heidegger of the hermeneutics of life in order to overcome the nihilism in Sein und Zeit. ${ }^{14}$ In a nutshell, what has to be accomplished is the following:

1. The bond between human beings and the cosmos has to be rehabilitated, since the "disruption between man and total reality is at the bottom of nihilism" (PL 234): a third way, evading both "isolated selfhood" and "monistic naturalism" (PL 234) has to be found.

2. This is not possible if the heritage of Cartesian dualism in philosophy that places such a strong emphasis on the mind, as opposed to matter, is not overcome. Instead of this narrow interest in the mere "tip of the iceberg of our being," the conditions for intelligibility, in other words, "the broad organic basis on which the miracle of mind is perched" (PE xii), should be subjected to thorough reflection.

3. It would be impossible to do this without an enquiry into the nature of the organism (PE xiii) and in particular of the body (PL 19). Jonas's manner of going about this task is to attempt an " "existential' interpretation of biological facts" (PL ix) whereby the Heideggerian notion of care is spread out through nature to form a natural teleology. ${ }^{15}$

4. In this way a true ontology that would lend itself to a transition to an ethics would be rehabilitated: "In purposiveness as such ... we can see a fundamental self-affirmation of being, which posits it absolutely as the better over against nonbeing. ... the mere fact that being is not indifferent toward itself makes its difference from nonbeing the basic value of all values, the first 'yes' in general" (PV 155/IR 81). 
5. An existential interpretation of life would provide a perspective on concern for life that implies at the same time concern for the other, "selfless fear" (PV 392) of threats against the life of the other and the duty of which the essence is formulated in the categorical imperative: "Act so that the effects of your action are compatible with the permanence of genuine human life on earth" (PV 36/IR 11, translation modified), that could, at least in principle, be used to develop a "series of practical instructions."16

This is, in a nutshell, what Jonas attempted, especially in Das Prinzip Verantwortung, but also in his subsequent essays. We should not fail to observe that even in this book, where Jonas seems surer of the prospects of his enterprise than anywhere else, he reveals some reservations about it: "In any case, for the sake of our first principle . . . we cannot avoid taking the imprudent plunge into ontology, even if the ground we can ever hope to reach there should prove no more secure than any at which pure theory must come to a halt. It may be suspended forever above an abyss of the unknowable" (PV 94/IR 45).

Now, instead of following the gradual unfolding of this argument, this "imprudent plunge into ontology" (as IR translates), this "excursion in ontology" (Ausflug in die Ontologie), and what ensues from it, I shall take up a hint of Hans Achterhuis's and approach this ambitious project from the end; that is, from the very last essays that Jonas published on this theme. In particular, the essay "On the Ontological Foundation of a Future-ethics" (Zur ontologischen Grundlegung einer Zukunftsethik) is worthy of attention, for, as is apparent from its telling title, it thematizes the essence of the Jonasian ontologico-ethical project. Hans Achterhuis contends that in this essay we find (though it is not explicitly formulated as such) an acknowledgement by Jonas that his project had failed. ${ }^{17}$ It is not difficult to find support for Achterhuis's point. If, in Jonas"s own assessment, the transition from is to ought "will likely for ever remain controversial" (PUV 130), if his Zukunftsethik is based on his own "metaphysical faith" (PUV 130), if he concedes that he (the author of the metaphysics of PV) does not have the metaphysics that he believes one needs for his project (PUV 137), if what he presents then is no proof (PUV 139), if he actually has nothing better to offer and perhaps a future metaphysician could do so (which implies that no past or contemporary metaphysician, according to his knowledge, could do so) (PUV140) - would we then not do better to close Jonas's works and archive them in a library for outdated metaphysics? Or, to be less harsh, should we not at least conclude that in a world where nihilism is the default setting, Jonas admits that he is not capable of contributing anything compelling for those who do not incidentally share his intuitions, beliefs, suppositions? ${ }^{18}$

My first answer to this question would be Yes: I have thus far distinguished two voices in Jonas's work and, insofar as this distinction is maintained, it will have to be conceded that the theological voice in Jonas's works has no ambition to attempt a universal grounding of ethics (and thus a refutation of nihilism), and 
that the metaphysical foundation of ethics has failed. ${ }^{19}$ From this perspective, Jonas's contribution to the question of the death of God is, at best, very limited.

\section{Second Approach: Jonas's Myth as an Alternative Route to Access his Project}

However, there is another way in which to read Jonas, one that probably would not correct all the weaknesses of Jonas's metaphysics but that would at least put his contribution on nihilism in a more positive light. Suppose we were to start with the following question: If Jonas does not succeed in speaking about "God" with his philosophical voice (in other words, if he fails to resuscitate the dead God of modern culture and thus overcome nihilism in this manner), and if he does not use his philosophy simply to ventriloquize his theological voice, is there something that can be heard in what he writes, perhaps something that could, strictly speaking, be said neither by the voice of theology, nor by the voice of philosophy? If the validity of all theology and metaphysics in his work is suspended, is there anything else left to be heard? I contend that this question should be answered in the affirmative and that this peculiar form of discourse - a discourse of the unsayable - is to be found in Jonas's myth, provided that this myth is not read simply as a theological text. The Jonasian myth, in my opinion, leaves intact the tension of the theological and the philosophical voices, but puts them in a different light. The myth would be a way to bring God back into ethical consideration, but it does so not so much by presenting God, as by letting God recede. From the perspective of his myth, the rest of his work might appear in a different light. According to the reading that I shall develop here, the Jonasian myth thematizes the essence of his work and does this in such a manner that it will help us to reconsider some of the detail thereof and perhaps lead us to a new appreciation of his work. The reason for not dismissing Jonas would then be his attempt at saying the unsayable albeit without the certainty that he would have liked it to have. Abandoning now the two-voice strategy of reading Jonas's work, in the rest of the article I shall attempt to identify the myth and its echoes throughout his work, as well as the tensions and continuations between this myth and the central tenets of his work.

In order to set the stage for this discussion, the essentials of this myth should be highlighted. ${ }^{20}$

In the beginning, God, or the divine, or the ground of being, decided to engage in the chance and limitless variety of becoming. By doing so, God left the world completely to itself, since having become completely immanent, this God left no remainder of himself ${ }^{21}$ with which to intervene in the process of becoming of the world. This was the risk of creation: God gave his image over to the becoming of the world. With the emergence and development of life God became aware of himself. Yet life is vulnerable and mortal and thus finite. Always under threat of death, life is stamped by the striving towards selfpreservation. Care for life is the response to the threat of extinction. As the series 
of life forms expands, the variety of temporal experiences that God has of himself also expands. All of this happens in an innocence beyond good and evil:

And then he $[=\mathrm{God}]$ trembles as the thrust of evolution, carried by its own momentum, passes the threshold where innocence ceases and an entirely new criterion of success and failure takes hold of the divine stake. The advent of man means the advent of knowledge and freedom, and with this supremely double-edged gift the innocence of the mere subject of self-fulfilling life has given way to the charge of responsibility under the disjunction of good and evil. To the promise and risk of this agency the divine cause, revealed at last, henceforth finds itself committed; and its issue trembles in the balance. The image of God, haltingly begun by the universe, for so long worked upon - and left undecided - in the wide and then narrowing spirals of pre-human life, passes with this last twist, and with a dramatic quickening of the movement, into man's precarious trust, to be completed, saved, or spoiled by what he will do to himself and the world. And in this awesome impact of his deeds on God's destiny, on the very complexion of eternal being, lies the immortality of man.

With the appearance of man, transcendence awakened to itself and henceforth accompanies his doings with the bated breath of suspense, hoping and beckoning, rejoicing and grieving, approving and frowning - and, I daresay, making itself felt to him even while not intervening in the dynamics of his worldly scene: for can it not be that by the reflection of its own state as it wavers with the record of man, the transcendent casts light and shadow over the human landscape? (PL 277)

In what follows, I argue why and how the work of Jonas would appear in a new and interesting manner if this myth is taken as a point of access and key to the interpretation of the rest of his philosophy.

\subsection{Nature of the Myth}

In the first context in which it appears (the essay "Immortality and the Modern Temper" in The Phenomenon of Life), it is said that this myth forms the "hypothetical background" that would be able to "validate those subjective feelings about an eternal issue which we experience in the call of conscience . .."22 (PL 274). But immediately afterwards, Jonas asks, without answering his own question: "But into what complete metaphysics would such a hypothetical fragment fit?" (PL 275) - this would indeed be a strange train of thought in which the background fits into what it is supposed to (fore)ground. That is, unless the place of this mythical fragment is to be read as one of inspiring its context even whilst not completely belonging to it. . .

In order to shed more light on this matter and to take the next step towards the introduction of this alternative perspective on Jonas's work, an idea that is merely mentioned by Albrecht Wellmer could be developed, namely that the myth is an extension of the essay "Gnosticism, Existentialism, Nihilism." 23 We have seen that Jonas, in the latter essay, considers the radicality of modern 
(existentialist) nihilism to consist in presenting reality as a non-caring abyss, as indifferent (PL 233). According to Jonas, at this point, a problem of inconsistency gapes in nihilism: "[W] hat about an indifferent nature which nevertheless contains in its midst that to which its own being does make a difference? .. . So radically has anthropomorphism been banned from the concept of nature that even man must cease to be conceived anthropomorphically if he is just an accident of that nature. As the product of the indifferent, his being, too, must be indifferent" (PL 233). In other words, how is it that, despite being the product of an indifferent process of formation of the cosmos, are we (capable of being or feeling) responsible? If someone objects that in fact he or she does not find himself or herself responsible (for instance, by claiming that responsibility is merely an epiphenomenon of the will to power), Jonas would have at least two tests for the sincerity of such a self-observation: (1) Does this person see Auschwitz as a purely indifferent event in the unfolding of the cosmos, and (2) Is the relation of parents to their child purely indifferent? ${ }^{24}$ Someone that would affirm these two statements would be a consistent nihilist; and, as I have already shown, Jonas acknowledges this theoretical possibility. ${ }^{25}$ Nothing that follows is strong enough to refute such a position absolutely. What follows would rather attempt to throw a shadow of doubt on the obviousness that it would have for such a nihilist. Jonas's myth, and its echoes that appear between the lines of his other texts, open a window on "the ethical" or "responsibility," not as a virtue but as the principle of ethicity. ${ }^{26}$

From the outset, a number of negative qualifications of this myth should be made: ${ }^{27}$

1. The God about which the myth speaks is not the God of metaphysics: Jonas does not go back to before Kant, but writes the myth in full cognizance of Kant's criticism of metaphysics. In fact, as Wellmer has indicated, he goes beyond Kant, in that Jonas's myth is not even an attempt at a conceptual justification of the metaphysical Ideas, God, Freedom, and Immortality. ${ }^{28}$ The myth takes the place of the regulative ideas of the reason in Kant, in that they pose a task rather than present any knowledge. ${ }^{29}$ In this way, the entire domain of what is, is placed from the start in a perspective of what ought to be.

2. Neither is this the God of the known religions; ${ }^{30}$ also, it is not irrelevant that the context in which it appears for the first time (PL chapter 11) is a purely philosophical reflection (on immortality). Furthermore, even though the God of this myth might, from the perspective of the death of God, appear very theological, from the perspective of theology in which God is both the creator and the legislator, the image of God in the myth would constitute an important concession ${ }^{31}$ - this God is suffering, changing, at risk in his becoming, and not omnipotent (cf. PUV 197203), ${ }^{32}$ in other words, if God is not dead, then he is at the very least very frail. Jonas's myth does not have the backing of tradition and institutional 
authority; it is a myth he invented himself, drawing on religious and philosophical sources. In fact, initially he did not even realize some of the theological implications of the myth that he would later develop (cf. PUV 197) and only later, in his "Notion of God after Auschwitz" text, did he tie it to the Jewish tradition (PUV 197).

3. Although Jonas qualifies this essay as "a piece of unconcealed speculative theology" (PUV 190), he explains soon after this that "such a piece of work is philosophical" (or that it could be) (PUV 191). He also claims the right of a philosopher to maintain the use of the notion of God on the sole basis of wanting to do so (PUV 193). The result of this is that the discourse on God in the myth is neither simply theological, nor simply philosophical, although it clearly draws on both modes of discourse.

Jonas is fully conscious of the unusual nature of this mode of expression. In a number of texts he specifies what he understands to be the performative and signifying nature of myth:

1. At the end of his essay on "Heidegger and Theology," he questions the applicability of a demythologizing representation of God, since it reduces claims about God to claims about human beings. Therefore, he states that the "final paradox [of the divine] is better protected by the symbols of myth than by the concepts of thought. Where the mystery is rightfully at home, "we see in a glass darkly." What does "in a glass darkly' mean? In the shapes of myth. To keep the manifest opaqueness of myth transparent for the ineffable is in a way easier than to keep the seeming transparency of the concept transparent for that to which it is in fact as opaque as any language must be. Myth taken literally is crudest objectification. Myth taken allegorically is sophisticated objectification. Myth taken symbolically is the glass through which we darkly see" (PL 261). The paradoxes "manifest opaqueness" and "seeing darkly" should draw our attention; so too, the insistence on the correct response (in other words, interpreting myth symbolically). In order to appreciate the myth for what it is, we would have to content ourselves with the sound of the echo after silence has come.

2. Such a myth or "likely imagination" (PL 275) - which its author permits himself in the "license of ignorance" (PL 275) - may be considered true, but only in a very particular sense: “ . . . in the sense in which myth may happen to adumbrate a truth which of necessity is unknowable and even, in direct concepts, ineffable, yet which, by intimations to our deepest experience, lays claim upon our powers of giving indirect account of it in revocable, anthropomorphic images" (PL 278). With an appeal to Plato, Jonas characterizes myth as "that pictorial [or figurative] means, but still credible supposition, that Plato allowed for the sphere beyond the knowable" (PUV 193). 
3. In the last essay of Philosophische Untersuchungen und metaphysische Vermutungen, where the term "myth" is not used, the content of the myth is found, albeit in a less narrative form ${ }^{33}$ (especially PUV 241-247), in the second half of the essay that is written under the reservation of "Suppositional Character of the Remaining Reflections" (Vermutungscharakter der weiteren Überlegungen) (title of §7). Here, Jonas is almost violent in his qualification of the truth content of what follows: "Everything that I have to say from here onwards, is a groping attempt and in all probability of someone who is mistaken" (PUV 230). He sees this, however, as inevitable and promises that the faith to which he proceeds then will attempt to be a faith of reason (Vernunftsglauben), not a faith of revelation (Offenbarungsglauben) (cf. PUV 230). The presentation of the "myth" or "supposition" is followed by a reflection on ethics, from which we deduce more about the "epistemological" nature of the myth: "Why may we not, like animals, do everything that we are capable of? Including self-destruction? Since being says so? But as is well known, as all modern Logic and Philosophy teach us, it doesn't say anything at all on this, no 'ought' follows from any 'is.' Now, all depends on the 'is.' One has to see it and one has to hear it. What we see, embraces the evidence of life and of the spirit [Geist] - witnesses against the doctrine of a nature that would be foreign to value and to ends. What we hear, is the call of the good that is seen, its inherent claim to existence. Our capability to see and hear makes us into beings that are called upon [Angerufenen] by its commandment of recognition and thus into subjects of an obligation towards it" (PUV 247). There seems to be another way to see and hear (other than what we do with our eyes and ears, but not without them) of which the myth gives us a glimpse; the myth presents in narrative form the largest horizon or perhaps the primal mood ${ }^{34}$ in which it becomes possible to hear the testimony and the appeal of reality: within this horizon, the mere fact of being capable of or susceptible to an evaluation concerning the good and responding to the fact that the good should be implies an obligation. This brings us back to the observation of an ethical sensitivity in the face of Auschwitz and the parent-child relationship. ${ }^{35}$ The myth reinforces a sensitivity for that which already exists, by placing that sensitivity in a picture in which the ethical agent belongs to a nonindifferent world.

Thus the myth does not present us with a grounding or foundation of ethics, but with a suggestive picture: if it is possible for someone to be solicited to a response by this suggestion, it is because the myth confronts us not with a representation of the world, but with an evocation of the appeal that characterizes our being-in-the-world (see Wellmer) or our primal mood profoundly. This appeal or obligation could be formulated in two typical questions: Why consider Auschwitz anything but an indifferent event lost in the immensity of the cosmos? 
Why consider the care of parents for their child as anything more than a mere biological event? In other words, the implied "epistemology" of the myth as a symbol is that the intelligible stretches beyond the knowable ${ }^{36}$ and the sayable: this form of intelligibility beyond the knowable is the question concerning anthropodisee; that is, the question of obligation that underlies all questions of truth.

But if all of this is accepted, how is the relation between the myth and the rest of Jonas's work to be understood? The answer to this question is the guiding theme of my second article. However, in order to complete the current study, I shall at least argue that the myth and its manner of functioning remains true to and gives expression to the principal concerns of Jonas's (later) work.

\section{The Intention and Aim of Jonas's Ethical Project in the Light of the Myth}

In order to gain insight into the way in which Jonas's myth incorporates the main concerns of his later work, it is necessary to remind ourselves of the broad interpretational scheme that he has proposed for human spiritual history. According to Jonas, every epoch is formed and informed by an all-encompassing implicit conviction concerning the nature of reality. In modernity, for instance, this all-encompassing conviction supports the progress of science and technology, but it is also reinforced and maintained by modern science and technology. It is this all-encompassing conviction that makes modernity what it is, in contradistinction to non-modern times and cultures; it is also this conviction that is constitutive of nihilism or the death of God. Understanding this conviction and responding to it is the essence of Jonas's philosophical programme and in particular of his myth. Thus, in order to understand the modern technical condition and the problem of nihilism and to react to it in a suitable manner as the task set out in the introduction - the implicit premise and inner logic of this all-encompassing conviction needs to be understood.

In the first essay of The Phenomenon of Life: "Life, Death and the Body in the Theory of Being," Jonas not only provides a typology of epochal convictions, but also explains how they work. Both of these are crucial for our understanding of his myth as a point of departure for a reaction against the nihilism of the technological era.

\subsection{Historical Typology of All-encompassing Convictions}

This essay divides the history of humanity into two opposing blocks, mediated by a long phase of transition: whereas initially human culture was carried by an all-encompassing conviction of a limited pan-vitalist world in which death was a puzzling exception (PL 8), contemporary people in modern societies live under the conviction of an immense extension of lifeless matter in which life is the puzzling exception (PL 10); dualism forms the two-thousand-year historical transition between the two extremes of vitalistic monism and materialistic or mechanistic monism (PL 12). Dualism, with its highest point in Gnosticism, expresses the tendency of an all-encompassing conviction about reality: that reality 
is not capable of rendering life-orienting values; in other words, a conviction according to which the world that humans inhabit is indifferent to value. The conviction of a lifeless or indifferent matter that surrounds human existence is an extension and radicalization of dualism, in that the basic dualistic structure is maintained but the spiritual content is emptied out to form a materialistic monism (PL 14). This situation of a hollow dualism is of course, to Jonas's mind, nothing but the "absolute vacuum, the really bottomless pit" of modern nihilism, in which "nature does not care" and in which people have to project their own meanings on a meaningless world (PL 233, discussed above). In short, the premise that makes up the very logic according to which the modern technological civilization unfolds is constituted by and made possible by an all-encompassing conviction that has the structure of a dualism hollowed out to a materialist monism.

Now, Jonas does not imagine for a single moment that we can return to a world of animism (PL 16). Instead, what he calls a "new, integral, i.e., philosophical monism" should absorb the polarity of the inherited dualism "into a higher unity of existence from which the opposites issue as faces of its being or phases of its becoming," and then adds that such a philosophical monism "must take up the problem which originally gave rise to dualism" (PL 17); that is, we need to think about the reality of life and death together without reducing the one to the other. It is well known that he undertook this task in The Phenomenon of Life but repeated and transformed it in Das Prinzip Verantwortung. But since we share the criticism levelled at those attempts, the question is now to see if the proposed alternative reading of Jonas from the perspective of his myth could be considered to remain true to this intention.

\subsection{Allowing for Another All-encompassing Vision of Reality}

In order to embark on the project of proposing a new monism - albeit a mythological, rather than a philosophical one - one needs to understand how an all-encompassing conviction works. The functioning of such a conviction is summarised by Jonas as follows: "Any problem is essentially the collision between a comprehensive view (be it hypothesis or belief) and a particular fact which will not fit into it" (PL 9). In the case of pan-vitalism, the anomaly of death was interpreted or given meaning by construing it as a deviant form of life. This need not have been done as a consciously adopted strategy; in fact, it probably was not. What is decisive is that the fact of death accrued a particular meaning in the context of a living universe.

This is then what Jonas attempts to do: to provide us with a new monism that is neither that of a pan-vitalism, nor that of a materialism, but one that could at the same time accommodate the historical fact of these manifestations of human culture, as well as their mediation through dualism. However, the kind of theory that serves to change the world and in which the human being is "the only remaining source and referent of value" (PL 195) and as such just another object reified (PL 196) - theory as it is known in modernity - is to be avoided from the outset, since its use would simply repeat its defects. In other words, 
this feat of finding a new monism cannot be achieved by means of modern science and technology because they remain true to the all-encompassing conviction of an indifferent universe. It seems to me that the strongest aspect of Jonas's attempt is the construction of his myth. This myth then, is to be understood as inseparable from the modern technological condition, in the sense that it is exactly this historical manifestation of human existence that most calls for another all-encompassing conviction. ${ }^{37}$ The latter need not be a philosophy, or the result of an argument, but it needs at least to be appropriated aesthetically, in the sense explained above.

\section{Conclusion}

The potential of Jonas's myth argued for in this article is that it can be used to manipulate the implicit all-encompassing conviction that people have of reality. This does not mean the construction of an entire framework for the interpretation of all aspects of reality. It only means effecting a glimpse of reality - or to be more precise, of the most striking aspect of people's being-in-the-world - in which the modern technological civilization could appear as the addressee of an appeal. Without such a glimpse, the logic of the technological civilization, the spontaneous unfolding of the sequence of technical ends and means, would simply remain self-evident. Questioning the technical civilization does not mean putting it to the test according to its own rules - since the question of effectiveness/efficiency and its answers are the essence of the technological logic itself - but rather means confronting it with a demand that does not belong to its own order. If the evocative potential of the myth is not accepted, this would mean, at least in this reading of Jonas, that the technological rules of the game of modernity form the ultimate horizon within which all things appear - this would also include things that would be called "ethical," such as the refusal of a repetition of Auschwitz or the insistence on parental care. In other words, these issues would appear as "the residue of the reduction toward the properties of mere extension which submit to measurement and hence to mathematics" (PL 10). It is when one's responses to Auschwitz and to parenthood are kept in mind that the severity of this situation becomes evident: it means, as for all things in the materialistic monism, that "the lifeless has become the knowable par excellence and is for that reason also considered the true and only foundation of reality. It is the "natural" as well as the original state of things. Not only in terms of relative quantity but also in terms of ontological genuineness, nonlife is the rule, life the puzzling exception in physical existence" (PL 10). What is precluded or at least suppressed in this picture is the affirmation of life and its concomitant care, which are the very concern of Jonas's philosophy.

However, it is true that the vast majority of people today find it objectionable even to consider repeating Auschwitz and they also find it necessary to maintain parental care. This could, of course, be considered from an objective or reifying point of view, namely as not saying anything about real values, but as saying something about (historico-culturally contingent) valuation (cf. PL 196). 
That Jonas is capable of repeating the intellectual exercise by which one arrives at such a conclusion has been demonstrated by reference to his article on "Contemporary Problems in Ethics from a Jewish Perspective" (PE Ch8). The abandonment of a foundational philosophy of ethics of necessity implies an acceptance of this possibility. However, Jonas's quest is to suggest a perspective in which this would be not the only alternative available. What other possible explanation could there be for the phenomenon that people find themselves and others responsible, and this in an apparently materialistic-monistic world? The answer is that the fact of finding someone responsible, of rejecting Auschwitz and approving of caring parenthood, testifies to a vision of things that depends on a horizon other than that of materialistic monism. It is this implicit horizon that is of concern to Jonas. It is this horizon that could be evoked by an act of verbal aesthetics, namely in his myth. And once the myth has been formulated, it could be deployed normatively: the myth is the provisional evocation of the implicit all-encompassing conviction that is required to make ethical judgment possible. If it can function in the described manner in the case of Auschwitz and parenthood, it can work in the same way all the time. Thus, in this reading of Jonas, an implicit hermeneutic circle is identified between the phenomenon of responsibility and his myth, a hermeneutic circle that encompasses all phenomena: the phenomenon of responsibility becomes understandable only in the light of the myth, and the myth has meaning only insofar as it is affirmed in the manifestation of acts of responsibility.

It should be clear that the insistence on Jonas's myth as point of access to his work presents the performative quality of his work as being aesthetic rather than foundational. As such, it remains true to the criticism of metaphysics, even though his myth takes the place that such a founding metaphysics would have taken. Furthermore, in so doing, Jonas's philosophy, in the identification of the problem of ethical agency and in its affirmation by means of his myth, remains respectful of human finitude. In the light of this myth, indifference does not become impossible (since the hermeneutic circle described above could be suspected of being a vicious circle), but counter-intuitive, or perhaps counter-imaginative. Since a discourse that points out that the current technological situation has made self-destruction possible does not amount to demonstrating that it ought not to be done; another perspective is needed in which the technical situation can appear as a problem. It is the appearance of the contemporary technical situation as an ethical problem that will be our concern in the second part of my double article.

If this mythological interpretation is plausible, then it invites us to reread Jonas's work from the perspective of this myth. From this perspective, Jonas's new metaphysical teleology of the organic world can no longer be seen as his ultimate argument for an ethics of responsibility, an argument of which the myth would be a narrative simplification. Instead, the myth should be seen as the essential point of entrance to the ethics of responsibility of which the metaphysical teleology is only one attempt to provide a symbolic reading and a 
"translation of the pictorial into the conceptual" (Übersetzung vom Bildlichen ins Begriffliche - PUV 197). Thus the metaphysics, even more than the myth, is a transgression of attempting to say the unsayable, as would be every response, not to the letter of the myth, but to what it speaks about. ${ }^{38}$ It is the theme of the myth that is decisive: despite the intellectual possibility of nihilism, we belong to the world in a normative manner. This is what is primary in and the origin of ethicity itself; it is the principle of responsibility. This would be the appealing strength that the text of Das Prinzip Verantwortung might maintain even if the metaphysics contained in the book is not accepted. The meaning of this principle of responsibility will become clearer when its status in the modern technological world is explained. This issue is addressed from the beginning of Part 2.

\section{Notes}

1 See "Responsibility in an Era of Modern Technology and Nihilism, Part 2. Inter-connection and Implications of the Two Notions of Responsibility in Jonas," (forthcoming in Dialogue).

2 The following abbreviations are used to refer to the works of Jonas in this and the follow-up essay: PL: The Phenomenon of Life. Toward a Philosophical Biology (Chicago/London: University of Chicago Press, 1966); PE: Philosophical Essays: From Ancient Creed to Technological Man, Englewood Cliffs, New Jersey: Prentice-Hall, 1974); PV: Das Prinzip Verantwortung. Versuch einer Ethik für die technologische Zivilisation (Frankfurt-am-Main: Suhrkamp, [1979]1984); TME: Technik, Medizin und Ethik. Zur Praxis des Prinzips Verantwortung (Frankfurtam-Main: Suhrkamp, [1985]1987); WpE: Wissenschaft als persönliches Erlebnis (Göttingen: Vandenhoeck and Ruprecht, 1987) and PUV: Philosophische Untersuchungen und metaphysische Vermutungen (Frankfurt-am-Main/Leibzig: 1992). For the purposes of this study, the books are referred to in the language - English or German - in which they first appeared. For Das Prinzip Verantwortung, I used the translation entitled The Imperative of Responsibility. In Search of an Ethics for the Technological Age (Chicago/London: University of Chicago Press, 1984 abbreviated as IR) - the page numbers indicated refer first to the page in the German text and then to the page in the English translation; for references without quotations, the page numbers refer to the German text, where that is the original and first publication.

3 For such a comparison see especially Eric Jakob, Martin Heidegger und Hans Jonas. Die Metaphysik der Subjektivität und die Krise der technologischen Zivilisation. (Tübingen/Basel: Francke, 1996), but also Lawrence Vogel, "Hans Jonas's Diagnosis of Nihilism: The Case of Heidegger," in International Journal of Philosophical Studies, 3, no. 1 (1995): 55-72. It should also be borne in mind that Jonas later expressed some reservations about the impression that his article could have created, namely that Gnosticism would be a trans-historical phenomenon (cf. "Religionsphilosophischer Diskurs mit Hans Jonas," in Ethik für die Zukunft. Im Diskurs mit Hans Jonas. Ed. D. Böhler \& I. Hoppe (München: C. H. Beck, 1994), 163-94, here 168-70). 
4 The title is somewhat misleading: what Jonas attempts (except perhaps in the last part of the essay) is not to present a Jewish perspective on a contemporary problem, but to give a perspective from the point of view of contemporary philosophy on the crisis facing ethical reflection and to which he suggests some Jewish responses. One is therefore not required to accept any aspect of the Jewish faith in order to be able to appreciate the perspective on nihilism that Jonas presents here.

5 This point is developed in more detail in PL Intro, ch. 1 and ch. 9, as well as in PUV ch. 5.

6 This point, amongst others, is elaborated on in PL Ch. 2, amongst other places.

7 This point is elaborated on in PE Ch. 1, TME Ch. 2, and in PV, amongst other places.

8 When Walther Zimmerli enumerates the meanings that the "abandonment of the world by God" (according to Jonas) has for the "modern philosophizing person," he also mixes the two notions. The three meanings are: (1) the existential auto-reference of human beings, (2) the ignominy of Auschwitz, and (3) the renunciation of the role of "replacement religion" played by science and technology. See Walther Zimmerli, "Philosophie in einer Gott-verlassenen Welt" in Ethik für die Zukunft. op. cit. 151-62, here, 156.

9 As he so brilliantly explains: "[W]hat I am speaking of is not the insinuation of extraneous ideas into philosophy through the all-too-human psychology of the philosopher. I am speaking of the legitimate continuation, in the medium of philosophy, of existential insights and emphases whose original locus was the world of faith, but whose validity and vitality extend beyond the reaches of faith" (PE 24).

10 It is in the form of this edition that I shall read the two last texts of PUV - I do this knowing very well that they have appeared elsewhere earlier. This choice is justified by the fact that Jonas compiled PUV and that as such it presents, not the real and only interpretation of these texts, but an important last interpretation of them.

11 "Religionsphilosophischer Diskurs mit Hans Jonas," op. cit. 177.

12 And similarly PUV 131-2: "Damit ist gesagt, daß vom Sein der Dinge selbst - nicht erst vom Willen eines persönlichen Schöpfergottes ihretwegen - ein Gebot ergehen und mich meinen kann."

13 However, it has to be noted that, earlier in the same book, concerning moral obligation, Jonas conceded "[es] ist theoretisch garnicht leicht und vielleicht ohne Religion überhaupt nicht zu begründen" (PV 36; Jonas added this phrase and the paragraph from which it is cited to the text of PV - it was not in the original essay reprinted in Hans Jonas, "Technology and Responsibility. Reflections on the New Task of Ethics," in PE 3-20, 13. See also PV 57-8 [formulated more neutrally]: "Es ist die Frage ob wir ohne die Wiederherstellung der Kategorie des Heiligen, die am gründlichsten durch die wissenschaftliche Aufklärung Zerstört wurde, eine Ethik haben können. . . . Aber eine Religion, die nicht da ist, kann der Ethik ihre Aufgabe nicht abnehmen." Hirsch Hadorn cites passages from before and after PV in which Jonas does indeed maintain that a creator God is needed to justify obligation. Instead of following her in maintaining a contradiction between the two opposing points of view, I make room for both, but as different voices; in other words, different kinds of discourse that each, within a particular textual context, claims to obey to honour different 
rules of validity (cf. Gertrude Hirsch Hadorn, "Verantwortungsbegriff und kategorischer Imperativ der Zukunftsethik von Hans Jonas," in Zeitschrift für philosophische Forschung 54, no. 2, (2000) 218-237).

14 'Lorsque Jonas dit que sa phénoménologie de la vie est 'existentialiste,' c'est parce qu'il voit s'anticiper dans la phusis et dans le moindre organisme qui en émane le souci de soi, dans le sillage de l'enseignement aristotélisant de Heidegger à Marbourg: tandis que, lorsqu'il accuse Heidegger de gnosticisme et de nihilisme, c'est justement pour avoir dans Sein und Zeit, en conformité avec l'héritage de Descartes, réduit la nature à une pure et simple Vorhandenheit, et fait de celle-ci l'antithèse absolue du mode d'être propre du Dasein, l'existence soucieuse à dessein de soi, conçue en définitive en termes nietzschéens comme pure volonté de volonté, à mille lieues des vues éthiques des Anciens." See Jacques Taminiaux, "Les enjeux d'une lecture gnostique de Sein und Zeit," in Sillages phénoménologiques. Auditeurs et lecteurs de Heidegger (Bruxelles/Paris: Ousia, 2002), 133-52, citation p.151.

15 See PL 86: "But future is the dominant time-horizon opening before the thrust of life, if concern is its primary principle of inwardness." Cf. also Jakob, Martin Heidegger und Hans Jonas, op. cit. 315.

16 "Eine Serie von praktischen Vorschriften," Jonas in "Vom Profit zur Ethik und zurück. Technik-Verantwortung im Unternehmen” (interview), in Ethik für die Zukunft. op. cit. 224-43, citation p. 241.

17 Hans Achterhuis, "Hans Jonas: ethiek en techniek," in De maat van de techniek. Ed. H. Achterhuis (Baarn: Ambo, 1992), 139-76, here 164-65.

18 For all his refusal of Jonas's metaphysics, Achterhuis's response to this question is negative. He suggests, without elaborating on his idea, that it would be possible to do a different reading of Jonas's attempt at founding ethics. His philosophy "then ceases to be a modernistic 'master narrative,' but becomes rather a post-modern attempt to convince and motivate the reader with all possible rhetoric[al] means, both rational arguments and images that make an appeal to the emotions. In Jonas's own words it becomes a call, an appeal that could lead to a change of mentality and attitude and to a different educational practice" (Achterhuis, "Hans Jonas: ethiek en techniek," op. cit. 165, my translation). The reading that I develop below is compatible with Achterhuis's opinion.

19 This failure should be deduced not only from Jonas, as cited above, but also from a number of commentaries; see, for instance, Hirsch Hadorn, "Verantwortungsbegriff und kategorischer Imperativ der Zukunftsethik von Hans Jonas," op. cit. and Gethmann-Siefert, "Ethos und metaphysisches Erbe. Zu den Grundlagen von Hans Jonas" Ethik der Verantwortung," in Philosophie der Gegenwart, Gegenwart der Philosophie, ed. H. Schnädelbach and G. Keil (Hamburg: Junius, 1993), 171-215. A valuable bibliography of literature on this subject is provided by Micha Werner in "Dimensionen der Verantwortung: Ein Werkstattbericht zur Zukunftsethik von Hans Jonas" in Ethik für die Zukunft, op. cit. 303-38, here 317n71.

20 The myth is found in PL 275ff, PUV $193 \mathrm{ff}$ and in a less narrative form underlies the last essay of PUV. The latter essay is included in this group, since it is here that one sees most clearly how the myth could be read as a narrative equivalent of Jonas's teleological metaphysics in PL, PV, and PUV. 
21 It is not clear what pronoun should be used in English for this God. I opt for a personal pronoun since the myth seems to indicate that, at least at the end, God has a personal being; the feminine personal pronoun would do just as well as the masculine.

22 That the mere emergence of feelings of obligation towards others does not suffice as a justification of ethics can be concluded (1) from Jonas's explicit criticism and rejection of subjectivism as a kind of manifestation of nihilism in ethics (PL 284, PE 171, but discussed above), and (2) from Jonas's insistence that a theory of responsibility as he conceives of it values the subjective sense of responsibility, only within a broader framework, namely as a personal appropriation of the objective validity of obligation (cf. PV 164) - in fact, in this passage, one clearly hears the same logic at work as in the citation under discussion: "Not the validity, to be sure, only the efficacy of the moral command depends on the subjective condition ..." (PV 164/ IR 86). In other words, in Jonas's commentary on his first presentation of his myth, he presents the myth as the source of validity for the subjective experience of the call of conscience.

23 Albrecht Wellmer, "Der Mythos vom leidenden und werdenden Gott. Fragen an Hans Jonas," in Endspiele. Die unversöhnliche Moderne (Frankfurt am Main: Suhrkamp, 1993), 250-6, here 250.

24 The first is implicit in the essay on God after Auschwitz; the other is the very special case in PV - cf PV 240, § title: "Archetypische Evidenz des Säuglings für das Wesen der Verantwortung". It is the very particular nature of the parent-child relation - one which seems to side step the long metaphysical argument of PV that allows me to consider it in the present context. Similarly, one could speak of Auschwitz as the same kind of "archetypical evidence" in PV. The latter presents a negative obviousness; the former a positive obviousness. But each is a manifestation of the fragility of the other.

25 "The answer to Auschwitz could quite perfectly be this: there is no God, in no meaningful way can there be a God that allows this" (cited above).

26 A detailed discussion of the two theories of responsibility in Jonas is the subject of my second article: "Responsibility in an Era of Modern Technology and Nihilism, Part 2. Inter-connection and Implications of the Two Notions of Responsibility in Jonas," (forthcoming in Dialogue), in particular $\S \S 4$ and 5.

27 In the current study, as far as the notion of myth is concerned, I limit myself to the texts in which the myth is told and those in which related ideas are expressed in a similar spirit as in the myth. A broader study would have to take into consideration the idea-historical development of Jonas's use of the notion of myth from his very earliest work on.

28 Cf. Wellmer, "Der Mythos vom leidenden und werdenden Gott." op. cit. 251.

29 Cf. PUV 191: "Wie Kant der praktischen Vernunft zugestand, was er der theoretischen versagte, so dürfen wir die Wucht einmaliger und ungeheuerlicher Erfahrung mitsprechen lassen in der Frage, was es mit Gott auf sich habe. Und da erhebt sich sogleich die Frage: Was hat Auschwitz dem hinzugefügt, was man schon immer wissen konte vom Ausmaß des Schrecklichen und Entsetzlichen, was Menschen anderen Menschen antun können und seit je getan haben?" Compare with Jean 
Lacroix, Kant et le Kantisme (Paris: PUF, 1966), 17-8; 12: "Si les Idées de la raison pure ne constituent pas proprement un savoir, du moins sont-elles régulatrices de notre pensée autant que de notre action. Elles guident notre marche infinie. Aussi ne sont-elles jamais données comme des objets: elles imposent des tâches. . . la raison et normative. Son caractère essentiel n'est pas la connaissance du fait, mais l'imposition du droit."

30 This is true even though the subtitle of the Auschwitz essay is "Eine jüdische Stimme" and even though Jonas himself indicates some Jewish sources of the myth. Although Jonas attempts to tie in his private myth "mit der verantwortlichen Überlieferung jüdisch-religiösen Denkens" (PUV 197), he notes in a number of places that his myth clearly contradicts this criterion. For an excellent discussion of the notion of God in Jonas, see R. Theis, "Dieu éclaté. Hans Jonas et les dimensions d'une théologie philosophique après Auschwitz," in Revue philosophique de Louvain 98 , no. 2 (1998): 341-57.

31 The extent to which these concessions signify a departure from inherited theological ideas and thus a challenge to (at least Jewish or Christian) theology could be measured, and its contours traced, in the critical appropriation by Jüngel (a far from philosophically insensitive theologian) of Jonas's essay - in which Jüngel attempts to bring back something of the notion of divine omnipotence. See Eberhard Jüngel, "Gottes ursprüngliches Anfangen als schöpferische Selbstbegrenzung: Ein Beitrag zum Gespräch mit Hans Jonas über den Gottesbegriff nach Auschwitz," in Gottes Zukunft-Zukunft der Welt, ed. H. Deuser et al. (München: Chr. Kaiser Verlag, 1986), 265-75. I would like to thank Georg Essen for this reference.

32 See also R. Theis, "Dieu éclaté." op. cit. $244 \mathrm{ff}$.

33 With some changes that need analysis elsewhere, for instance, the change of the dominant "God" to the use of "Geist" or "Urgeist". The Leitmotiv of the "extreme Selbstentäußerung des Schöpfergeistes im Anfang der Dinge” (PUV 242) or "Machtverzicht Gottes" (PUV 245) is, however, undeniable. We should, in my view, qualify this essay as an intermediary attempt at an "Übersetzung vom Bildlichen ins Begriffliche" (PUV 197); in other words, of facilitating the symbolic appropriation of the myth (see $\S 6$ below).

34 Wellmer ("Der Mythos vom leidenden und werdenden Gott," op. cit. 252) analyses and summarises this "aesthetic" interpretation of the performative character of the myth with admirable precision: : "Wenn der Mythos sagt, was 'in direkten Begriffen unsagbar' ist, so heißt das zunächst: er ist ein Bild, ein Bild nicht des Menschen, sondern der Menschen-in-der-Welt. In solchen Bildern blitzt eine Wahrheit auf, aber wenn wir begrifflich zu sagen versuchen, was in ihnen aufblitzt, geraten wir notwendigerweise in Aporien und Widersprüche (das ist es ja, was gemeint ist, wenn wir sagen, daß das, was das Bild sagt, ‘begrifflich’ unsagbar ist.) Daß das Bild anthropomorph ist, heißt hier ja nicht, daß es wie eine Metapher gebaut ist (die vielleicht Erkenntnis vermitteln kann), sondern daß es mit Worten operieren muß, die dem, was das Bild zum Ausdruck bringen soll, eo ipso unangemessen sind: Zwischen Gemeintem und Gesagtem besteht eine unüberbrückbare Kluft - nichts anderes meint das Wort 'unsagbar.' Wir kennen freilich ein Paradigma, wo diese Kluft sich 
schließt, weil sie gleichsam ins Innere des Bildes verlegt wird und der Anspruch, mit dem Bild etwas sagen zu wollen, verschwindet: dies Paradigma ist das ästhetische Bild."

35 Cf. Jean Greisch, "L'amour du monde et le principe responsabilité," in La responsabilité. La condition de notre humanité. (Paris: Editions Autrement, 1994), 72-89, here 80 .

36 In accordance with the spirit of Kant's philosophy, Jonas writes: "Denn wer das Scheitern in Sachen des Wissens in Kauf nimmt, ja, von vornherein auf dies Ziel überhaupt verzichtet, der darf in Sachen von Sinn und Bedeutung sehr wohl über solche Dinge nachdenken" (PUV 191).

37 The myth is a narrative that could give an account of the universal human history, including the opposite forms of monism and the dualism that mediated them; at the same time it provides at least an aesthetic provocation of the possibility of the overcoming of the latter (nihilistic) monism.

38 The last essay of PUV ("Materie, Geist und Schöpfung") would then take a middle position between the myth and the metaphysics of PV. For the notion of saying the unsayable, see again Wellmer, "Der Mythos vom leidenden und werdenden Gott," op. cit. 252, cited above. 